\title{
Envisioning the political ecology of mitigation in a microelectronic disaster setting
}

\author{
Peter C. Little ${ }^{1}$ \\ University of Louisville, USA
}

\section{Introduction}

The mitigation of environmental contamination and toxic disasters is complex and open to critical discussion on many fronts. ${ }^{2}$ Most certainly, like all socio-natural disasters, toxic industrial spills expose broad linkages between economy and ecology and often reconfigure local and national discourses on, among other things, corporate responsibility and negligence, contamination and mitigation. The large scale cases of such toxic disasters are many, but two stand out in particular: British Petroleum's Deepwater Horizon oil spill in the Gulf of Mexico in 2010, and the Fukushima Daiichi nuclear disaster in Japan in 2011. To date, however, the subject of mitigation-how to make sense of the social dimensions of toxics mitigation, how mitigation decisions are made, how mitigation is experienced by the mitigated, how mitigation fails to restore trust, and how relations between science and the public remain contentious despite mitigation efforts-has not been adequately grounded by ethnographic description couched in political ecology theory and practice. This is despite the fact that organizational theory address this to some degree, through sociological research on hazards (see Bogard 1988). Attention to local, concrete aspects of the "mitigated" environment in anthropology and political ecology is weak, if not completely missing, despite some recent ethnographies of contamination and toxic environments (Singer 2011; Little 2010; Auyero and Swistun 2009; Checker 2005; Allen 2003; Petryna 2002). Attention to the political ecology of toxics mitigation remains a little explored domain of anthropological and political ecology research. Ethnographic mitigation studies, as discussed in this article, can meaningfully augment this emerging synthesis of research on political ecology, risk society, and the anthropologies of toxic environments.

In short, this article encourages the tightening of the association between risk society and political ecology, suggesting that the narrative of mitigation, like the "narrative of risk is a narrative of irony" (Beck 2006:329). Toxics mitigation, no matter what the chemical substance in focus, is a "technique of visualization, a symbolic form" (Beck 2006:332) of responsibility that rarely results in the deletion of the perception of risk or the restoration in trust and security. Mitigation is a feature of what Beck (1999) would describe as the 'new politics' of risk. My experience has been that scientists and other members of officialdom, and anti-toxics activists, all perceive mitigation to be the solution - they even see it as a laudable precautionary action. This article draws on ethnographic data to explore the lived experiences and narratives of mitigation unfolding in a toxic waste site in New York state, and discusses how the political ecology of mitigation might inform contemporary discussions of toxic environments and their repair in the environmental social sciences.

Of course, the political ecology of mitigation perspective I focus on here didn't come out of thin air. It entered my thinking during an interview with a middle-aged woman on a brisk winter day in Endicott, New York in February of 2009. Endicott is a small town of about 13,000 people in the Southern Tier region of western New York (Figure 1). It holds a special place in the history of the Computer Age, as the birthplace of International Business Machines Corporation (IBM). It has a less popular place in the history of toxic hightech production. Frustrated because IBM polluted her neighborhood with a toxic plume of trichloroethylene (or TCE), a chlorine-based chemical solvent that was heavily used at the IBM-Endicott plant for chipboard manufacturing processes, one respondent told me that;

IBM polluted this place and now they come here and put these mitigation systems on all the homes and then wipe their hands. They say they have fixed the problem, but I don't think it is right. Don't mitigate me and tell me everything is ok.

My confrontations with this kind of local frustration enlarged my perspective on the ways in which toxics mitigation across corporate entities and the State exemplifies neoliberal mitigation in the sense that it "hinges

\footnotetext{
${ }^{1}$ Visiting Assistant Professor, Department of Anthropology, University of Louisville. Email: littlepe@onid.orst.edu. The research conducted for this article was supported by a dissertation improvement grant from the NSF Decision, Risk and Management Science Program. I wish to thank Bryan Tilt and David A. Sonnenfeld for their comments and suggestions on an earlier version. This article appears in a JPE Special Section of Eric Wolf Prize papers edited by Casey Walsh.

${ }^{2}$ According to the Oxford English Dictionary, mitigation comes from the Latin term mitigatus and mitigare or "to make mild or gentle."
} 
upon the active mobilization of state power [and] exacerbates regulatory failure" (Brenner and Theodore 2007:154, emphasis in original).

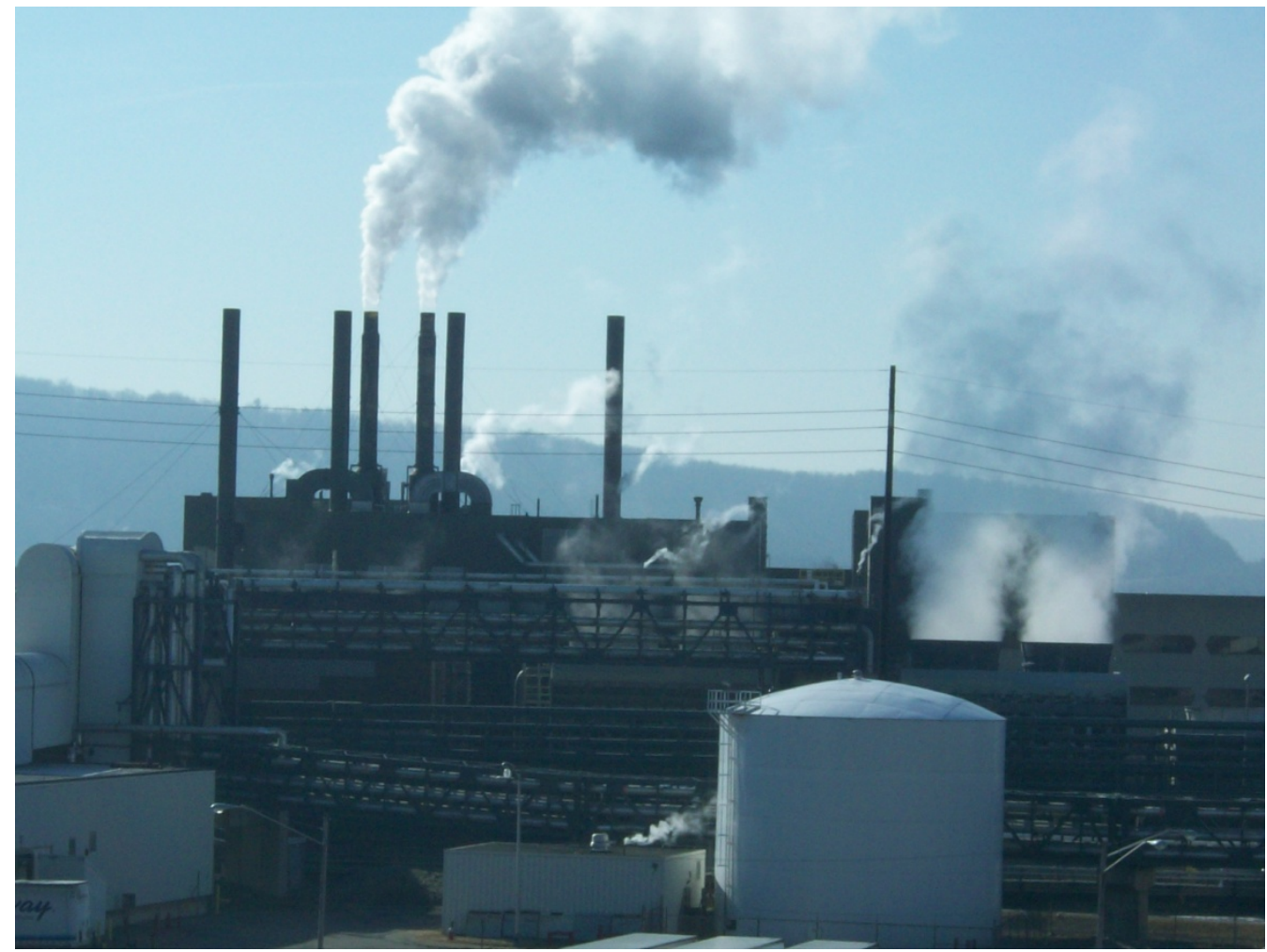

Figure 1: IBM's Plant \#1, Endicott, New York. Photo by author.

Endicott is one of many "contaminated communities" (Edelstein 2004) or "sacrifice zones" (Lerner 2010) struggling with durable ambiguities that outlast corporate-state clean-up efforts, and the scads of technical government agency reports claiming low or minimal public health risk. Local responses this corporate-state mitigation effort, and local critiques (Figure 2, as one community activist sees it), expose the politics of caring that emerge when IBM and the State wash their hands of toxic ruination via the deployment of 'mitigation systems.' Attending to the social and political experience of this trichloroethylene risk softening process, political ecology can help develop inroads into mitigation debates by further investigating the politics and theory of "repair" (Henke 2008). I will contend that mitigation is a feature of the "risk society" that calls for insight from critical political ecology. Three interrelated questions guide this charge. First, if mitigation truly mitigates, why does local mitigation skepticism persist? Second, what are the consequences of mitigation decisions? And third, how do these 'side-effects' of toxics mitigation open mitigation up to political ecological critique?

Envisioning the political ecology of mitigation, as it will be argued here, calls for an ethnographic approach cognizant of politics of knowledge and expertise that invoke competing visions of mitigation in general and the efficacy of mitigation technologies and science in particular. Mitigation decisions are political and not simply scientific decisions. The political ecology of mitigation pays close attention to the practices and processes through which mitigation is wielded and negotiated. In this sense, envisioning the political ecology of mitigation is about "envisioning power" (Wolf 1999), showing how power figures strongly in shaping the circumstances of cultural production. As Wolf rightly argued, these power relations need to be demonstrated, not assumed. Power, it will be suggested here, shapes the circumstances of mitigation decisions, especially in sites of contamination like the IBM-Endicott Superfund site where IBM and New York State's Department of Environmental Conservation colluded to make an exceptional case for "responsibly" mitigating the threat of TCE vapor intrusion in homes affected by the IBM spill. To effectively counter this corporate-state exceptionalism, the political ecology of mitigation I explore here also rests on the assumption that the "implications of the political for practical action" matter in communities experiencing mitigation efforts after toxic onslaught (Paulson, Gezon, and Watts 2003). In other words, I believe a; 
...more explicit conceptualization of power and politics is needed to better operationalize research on environmental changes and conflicts and to develop better ways of addressing practical problems of resource degradation and social marginalization [and community mitigation]" (Paulson, Gezon, and Watts 2003:209).

Mitigation is also a problem that needs greater conceptualization and practical ethnographic engagements that attend to the discourses and material conditions and processes that inform the social, emotional, political, and epistemic constitution of and response to risk mitigation (Little 2012a).

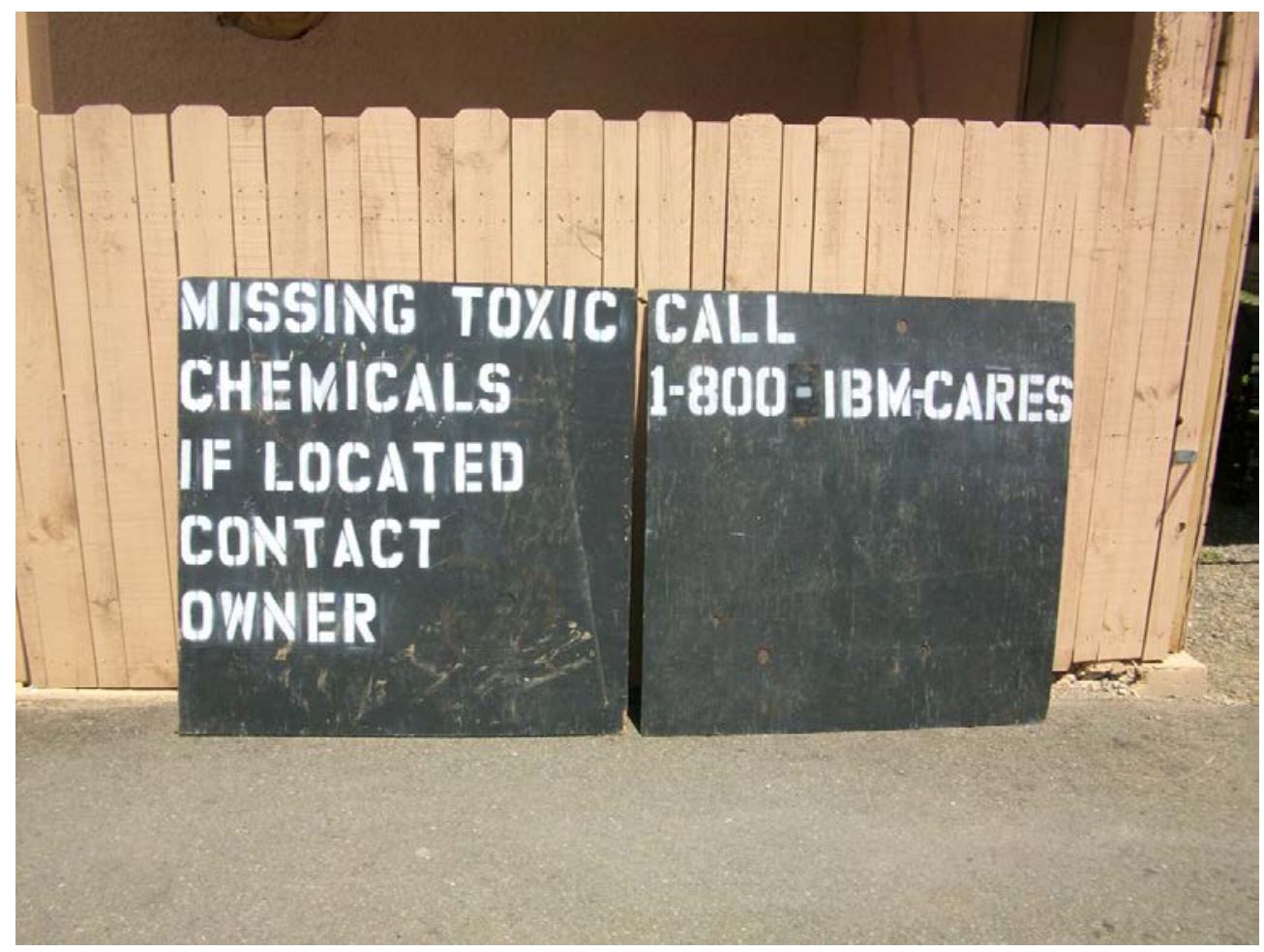

Figure 2: Local critique of IBM corporate social responsibility. Photo by author.

The article will be organized as follows. First, I provide a very brief history of IBM's development in this small New York town, and how Endicott became the nation's largest site for the mitigation of TCE vapor intrusion. I discuss the emergence of vapor intrusion science and policy, focusing in particular on how mitigation decisions figure in emerging vapor intrusion debates. Next, I engage some ethnographic research findings (both qualitative and quantitative) from fieldwork carried out in 2008-2009. I draw on these data to expose the multiple ways in which mitigation and the efficacy of risk mitigation is locally interpreted and made meaningful in ways that differ from those of scientists and regulators engaged in vapor intrusion science and policy. Finally, I discuss the ways in which these findings demonstrate the need for a deeper understanding, a more political ecological understanding, of the socio-political nature of toxics mitigation.

\section{Endicott, birthplace of IBM and toxic vapor hotspot}

In 1924, Endicott became home to the first manufacturing plant of International Business Machines Corporation (IBM) and quickly became the base camp of production and innovation of modern computing technologies. The IBM-Endicott plant boomed and busted, and became heavily contaminated. In 2002, IBM sold its Endicott facility and today the community is home to a contentious toxic plume, containing a particular chemical of concern known as trichloroethylene or TCE, that has contaminated a groundwater source spanning over 300 acres of residential and business use. Over 500 homes and nearly 1,100 residents have been "mitigated," meaning homes have been retrofitted with venting systems to "control" for what is called vapor intrusion, a process by which volatile contaminants (e.g., TCE) found in groundwater sources migrate into overlying buildings.

Listed under the US Environmental Protection Agency's National Priorities list of hazardous waste sites (or Superfund Sites) Endicott has transformed from a place of electronic production and modernization 
to a place of toxic intrusion and elusive mitigation. Peoples' place attachment has certainly been uprooted and reworked, making life in Endicott's toxic plume an unsettling experience, despite what some local activists and state regulators call a laudable cleanup effort on the part of IBM and the New York State Department of Environmental Conservation (NYDEC). This state-corporate cleanup effort has continued since 1978, when IBM reported its first spill of industrial effluent into the village's groundwater. One resident has attempted to notify the public of this unfortunate situation by placing a sign in front of his building (see Figure 3).

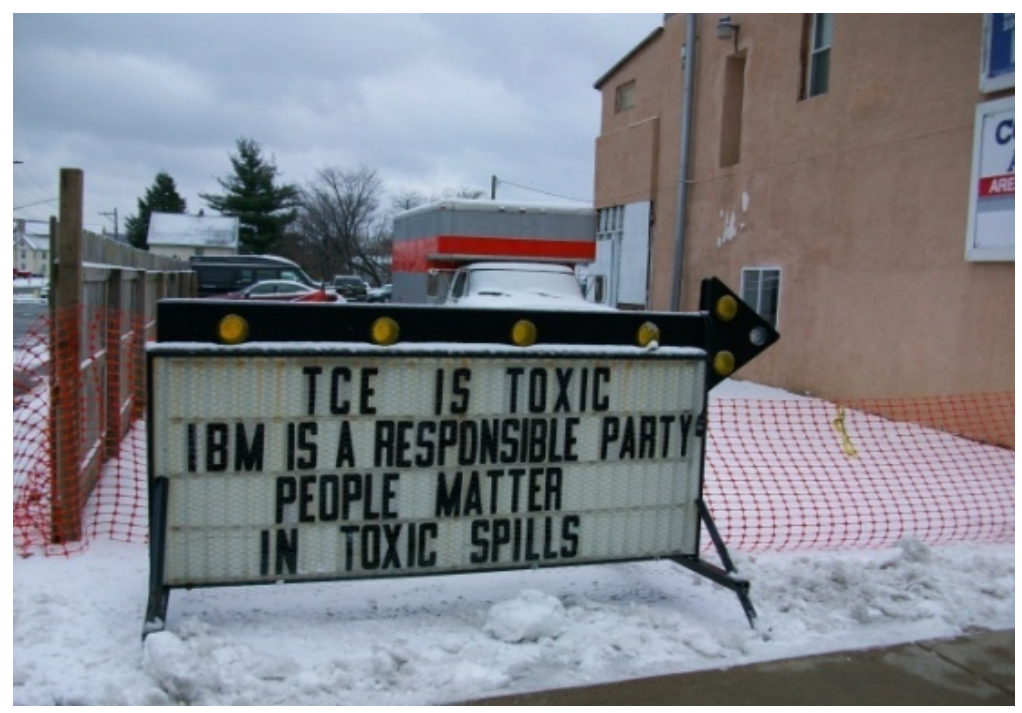

Figure 3: One Endicott residents' message to the public. Photo by author.

In early October 2008, I attended a two-day classroom training entitled "Vapor intrusion pathway: a practical guide" in Portland, Oregon that was organized by the Interstate Technology and Regulatory Council (ITRC). Established in 1995, the ITRC is a state-led and government-funded ${ }^{3}$ coalition made up of state and federal regulators, industry representatives, academics, and stakeholders working together "to achieve regulatory acceptance of innovative environmental technologies and approaches" (ITRC 2007). In this training I was told by one the instructors that Endicott was a good example of a site where the decision to mitigate was clear, given specific site characteristics that included, but were not limited to, the extent of detectable TCE levels and the relatively shallow distance between the contaminated groundwater and the concrete slabs of homes. In other words, "blanket mitigation"-the term commonly employed for decisions leading to the mitigation of all homes within a zone of contamination with a known or expected threat of vapor intrusion-made sense in Endicott. As he put it, "Some mitigation decisions are a slam dunk. You know they need to be mitigated."

Endicott is one of two well known vapor intrusion sites to result in a "blanket mitigation" decision the other site is known as the Redfield site in Colorado. But, as vapor intrusion scientists told me, mitigation does not mean that monitoring is no longer necessary. Post-mitigation monitoring generally involves monitoring the mitigation technology (e.g., sub-slab depressurization system) to see if it is functioning properly. In rare cases, post-mitigation monitoring can involve soil gas sampling and in-door air tests. But, most of these tests cost money, and so monitoring the mitigation system is the most cost-effective option. According to the U.S. EPA, installation costs from $\$ 1,500-\$ 5,000$ for active venting systems like the ones populating the Endicott landscape and the cost of annual operations and maintenance can range from $\$ 50$ $\$ 400$ (USEPA 2008). Continued air monitoring and lab costs for analysis per home can range from \$8,000$\$ 12,000$ and can vary with monitoring duration.

There is general agreement among environmental scientists and engineers that mitigation technologies do in fact do a good job of mitigating vapors, but to maintain the "control" of vapor intrusion these systems do require periodic maintenance and can't mitigate $100 \%$ of all volatized organics in the indoor air. Even after the installment of these mitigation systems, monitoring of the TCE plume continues (Figure 4).

\footnotetext{
${ }^{3}$ ITRC is funded primarily by the U.S. Departments of Energy, Defense, and the U.S. Environmental Protection Agency. It also receives funding from the ITRC Industry Affiliates Program (IAP).
} 


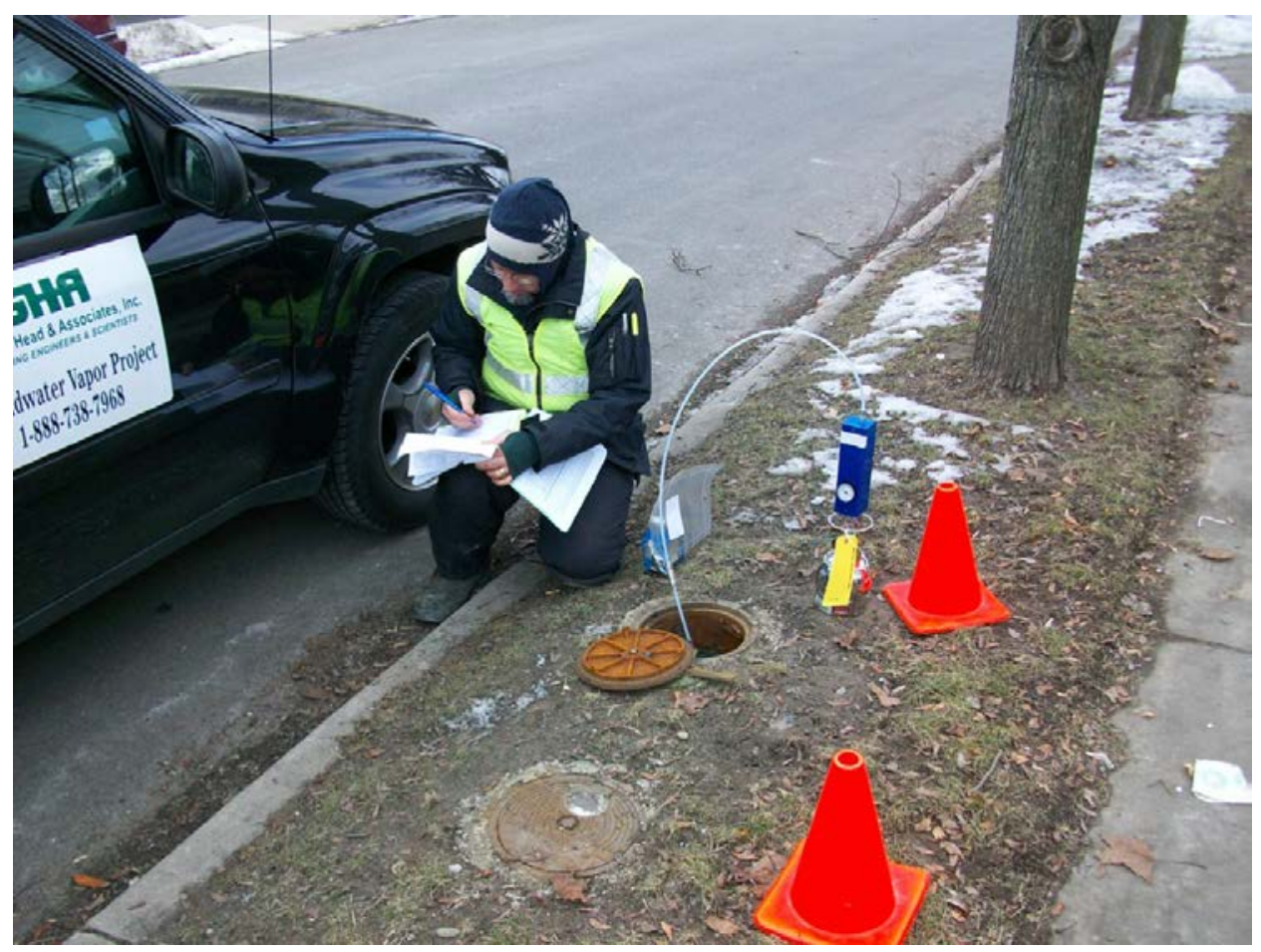

Figure 4: An expert measuring groundwater vapors in Endicott's TCE plume. Photo by author

The vapor mitigation systems (VMSs) used in Endicott are the same technologies used to mitigate radon gas, which results from the natural decay of uranium found in the earth's soil and water. VMSs (or subslab depressurization systems) are applicable for slab-on-grade building construction. VMSs are technologies designed to continuously lower pressure directly underneath a building floor relative to the pressure within the building. The resulting sub-slab negative pressure inhibits soil gases from flowing into the building, thus reducing, in the case of Endicott, TCE vapor entry into homes. The TCE vapors caught in this negative pressure field are collected and redirected into the ambient air (or the air outside the building). The depressurization under the slab is typically accomplished with a motorized blower. The VMSs in the IBMEndicott plume have a 90 watt motor that runs 24 hours a day. The blower draws air from the soil beneath the building and discharges it to the atmosphere though a series of collection and discharge pipes. According to the U.S. EPA (1994), these mitigation technologies are "a system designed to achieve lower sub-slab air pressure relative to indoor air pressure by use of a blower-powered vent drawing air from beneath the slab." A pressure gauge determines whether or not depressurization is occurring.

Mitigation is considered by activists, vapor intrusion scientists, and regulators to be a just vapor intrusion risk management decision. None of these groups of stakeholders tends to question the efficacy of these technologies to mitigate vapor intrusion risk, arguing that VMSs have helped to achieve the very low action levels required for indoor air remediation. Surely, if properly installed, these technologies can mitigate the effects of TCE vapor intrusion and achieve indoor air action levels, ${ }^{4}$ levels of which have been ardently contested in states like New York that have or once had a productive industrial sector.

There is also a "pro-mitigation" discourse at work in Endicott and in other sites where vapor intrusion is a concern. In Endicott and beyond, community stakeholders engaged in TCE activism and vapor intrusion activism are strong promoters of mitigating homes in areas at risk of vapor intrusion. As Lenny Siegel, cofounder of the Center for Public Environmental Oversight, community stakeholder and technical advisor to communities impacted by vapor intrusion, puts it; "Fortunately, it is relatively easy and inexpensive to prevent vapor intrusion. Subslab and submembrane depressurization systems, developed through decades of response to radon intrusion, can prevent the flow of contaminants from the subsurface into buildings" (Siegel 2009:6). Siegel warns that although mitigation systems like those installed in Endicott can be an effective

\footnotetext{
${ }^{4}$ Activists in New York have pushed the state to reduce the TCE guideline from 10 micrograms per cubic meter to 5 micrograms per cubic meter, and the New York State Vapor Intrusion Alliance is working to lower that action level to meet levels set by states with more protective standards. Thus far, California, Colorado, and New Jersey have the most protective standards, which range from 0.016 to $0.02 \mathrm{mcg} / \mathrm{m}^{3}$.
} 
form of vapor intrusion mitigation, "they only work as long as they work. To ensure that building occupants are protected, mitigation should be anchored in long-term management, which includes operation and maintenance, monitoring and inspection, contingency planning, notification, institutional controls, and periodic review" (2009:8, emphasis in original).

Vapor intrusion activists and community stakeholders believe in this pro-mitigation effort and point to the fact that mitigation decisions are often most contentious because VMSs are offered to some residents and not others based on the boundaries and concentrations of the VOC contamination. In one stakeholder report (Siegel 2008), one activist from a vapor intrusion site in Dutchess County, New York contended that;

I think any home that is between two other homes needing mitigation should be mitigated. I have come to that conclusion by putting myself in that person's place. How would I feel knowing that all around me the air is contaminated and my home is not protected should the toxic vapors decide to invade my home? I feel the same way for homes that are considered just outside the contaminated [zone]... The only way to breathe easy is to clean the plume that is the cause of the contamination.... I still do not understand why agencies decide to monitor and not mitigate should they find contamination since in many cases it costs less to mitigate than it does to monitor (Siegel 2008:5-7).

What follows is the perspective of one DEC scientist and vapor intrusion expert working on the IBMEndicott site from the New York State Department of Environmental Conservation (NYDEC). He believes the mitigation decision has "kept people from being exposed" despite a clear technical challenge of fully remediating the TCE plume His detailed knowledge of the history and particularities of the IBM-Endicott site mitigation decision are informative;

The two key things as far as the IBM issues specifically, is that we fairly quickly identified the structures that were potentially impacted and put mitigation systems on. I mean we started sampling in the beginning of 2003 and by that summer I think we had probably identified 85 or 90 percent of the homes that we ultimately offered mitigation systems to. We continued to do sampling for the next couple of years, but you know there was a huge effort to get our arms around the problem as quickly as possible. People worked very hard to do that. I did and folks here did, as well as IBM. So since then the emphasis has really been on, ok, we have kind of put the band aids on, we have kept people from being exposed, now what can we do to reduce the source of this contamination, to clean the groundwater up, both on-site and off-site. We have been making, I think, substantial progress in that effort...We have pretty much isolated the groundwater onsite and improved the containment on-site, and we are seeing concentrations decreasing in the groundwater off-site. There is probably a point at which you reach some sort of point where, I mean, like the cleaner it gets the more difficult it is to get cleaner. At some point there is a fairly limited amount of mass left and it can be in places where it is hard to get out. So that is a technical challenge in that respect, but we have actually accomplished quite a bit that way and expect to make progress on that.

During my interview with this official, he also assured me that the VMS system works, joking that "we don't need a new theory of physics. They work." I explained to him that many residents of the plume that I interviewed complain that nobody has retested the indoor air to assure them that the mitigation system is working. After sharing this finding with him, he responded;

Well, by and large, once we put a system on we do test it physically. I think that is the most important thing because what we are talking about with these systems is changing the physics of flow of contaminants beneath the house. It's about capturing those contaminants in a suction system before they can migrate into the house. So if you put a system in properly and you show through the physical testing that it's in properly, that's a pretty compelling line of evidence that the system is working. Because there were so many homes mitigated in Endicott we sampled only about ten percent, about 45 or 50 homes, of them over a range of concentrations that were in the indoor air. We sampled these homes after they had been mitigated and those data are also compelling. The chemical data basically substantiated the physical data that these things do reduce the concentrations. When we look at it and our management looks at it, those tests are not cheap. I mean it costs about a $\$ 1000$ a test. When we have compelling evidence that says the house is basically been properly mitigated, we say that there is probably a better way to spend it, like maybe looking for other houses. Again, you know, I don't think there is a sound technical basis for going back on a regular basis to test chemically these houses. In fact, I coauthored an article recently on this issue. The other author of the article has sampled homes at his site [the Redfield site in Denver, Colorado] every quarter for like 8 years and there is really 
no change. The data continue to show that the systems are working. So we are not looking only at data collected in New York, but data that has been collected elsewhere. All the data points in that direction.

As will be explored in more detail below, my ethnographic findings point to an omnipresent sense of ambiguity and frustration among residents living in mitigated homes. This NYDEC official explained that he understands the frustration that residents go through, but he is also "comfortable" knowing that the mitigation technology works, which puts him in a sticky position;

I understand that people want certainty. I am pretty comfortable with the way that we install the systems and test them afterwards physically, and again, some chemically. It just becomes a question of, you know, is it a good use of resources to continue to prove that what you did is good.

Beyond the obvious "cost-effective" discourse here, there is another crux that exposes for me the political ecology of toxics mitigation. Capital and scientific expertise are welded to establish proof and support action or inaction, but the goodness or 'rightness' of mitigation is not necessarily felt, realized, or experienced on the ground by those living in contaminated communities like Endicott.

\section{Listening to the "mitigated"}

At the heart of my research in Endicott is a desire to better understand how residents of the TCE plume make sense of toxics repair, intervention, and mitigation. Endicott was once referred to as "valley of opportunity," a Big Blue landscape that at its peak was inhabited by 14,000 IBM employees. Today, Endicott is a "valley of mitigation," the home of the nation's largest concentration of vapor mitigation systems. These mitigation technologies were a "gift" from IBM and the NYDEC and other vapor intrusion regulators and scientists call the Endicott Superfund site a good example of "blanket mitigation," whereby the decision to mitigate is based on site-specific considerations that usually call for long-term measures (e.g., mitigating 500 homes) because the complete removal of TCE from the groundwater source is considered technologically infeasible. In many ways, what cannot be fully remediated is consigned to mitigation, and this is how the mitigation decision-making process unfolded in Endicott.

Next, I draw on narratives from in-depth ethnographic interviews and quantitative survey data to explore local understandings of the mitigation effort and the lived experience of residents living in "mitigated" homes in the IBM-Endicott plume (see Figure 5). Despite the pro-mitigation discourse coming from both state and activist spheres, as mentioned above, the ethnography of residents living with mitigation in the IBM-Endicott plume reveals a particular theme, durable ambiguity, that one might think would have been softened by IBM and NYDEC mitigation efforts and pro-mitigation activists. Another theme that has become a popular source of concern for communities threatened by vapor intrusion in Endicott and beyond is property devaluation and the fear that having a mitigation system stigmatizes the home and marks it as a property threatened by vapor intrusion regardless of its "mitigated" status. Local residents' narratives also expose what I will call the iatrogenesis of mitigation. In other words, mitigation is a "treatment" that actually introduces new forms of distress and frustration for homeowners. ${ }^{5}$

The aim of these mitigation narratives is to better understand the social context of life mitigated. It is important to note that "blanket" mitigation in Endicott did not lead to a reclassification of Endicott's Superfund status. The IBM-Endicott site is still listed on New York State's Inactive Hazardous Waste site registry as a Class 2 site, meaning that the TCE plume still poses a significant threat to human health and the environment, as was determined back in $1984 .^{6}$ It also has not lead to the "mitigation" of local TCE risk perception, as will be shown below. When it comes to discussions of risk, it is more often than not the case that "there is no scientific monopoly, since there is rarely expert agreement either on what constitutes acceptable risk, or on how it may be managed" (Caplan 2000:3). What results from this situation is a social experience of TCE risk that is very similar to the social experience of TCE risk mitigation and the possibility of the proliferation of "public criticism and disquiet" (2003:3) despite what many considered to be a laudable risk management decision.

\footnotetext{
${ }^{5}$ Iatrogenesis is a term commonly used in medical discourse and comes from the Greek expression, "brought forth by a healer." In this case, the two-headed "healer" is IBM and the New York State Department of Environmental Conservation, and the vapor mitigation system the selected treatment option.

${ }^{6}$ Between 1986 and February 2004, the IBM-Endicott site was listed as a Class 4 Superfund site, meaning the site required continued management even after the sale of the IBM plant.
} 


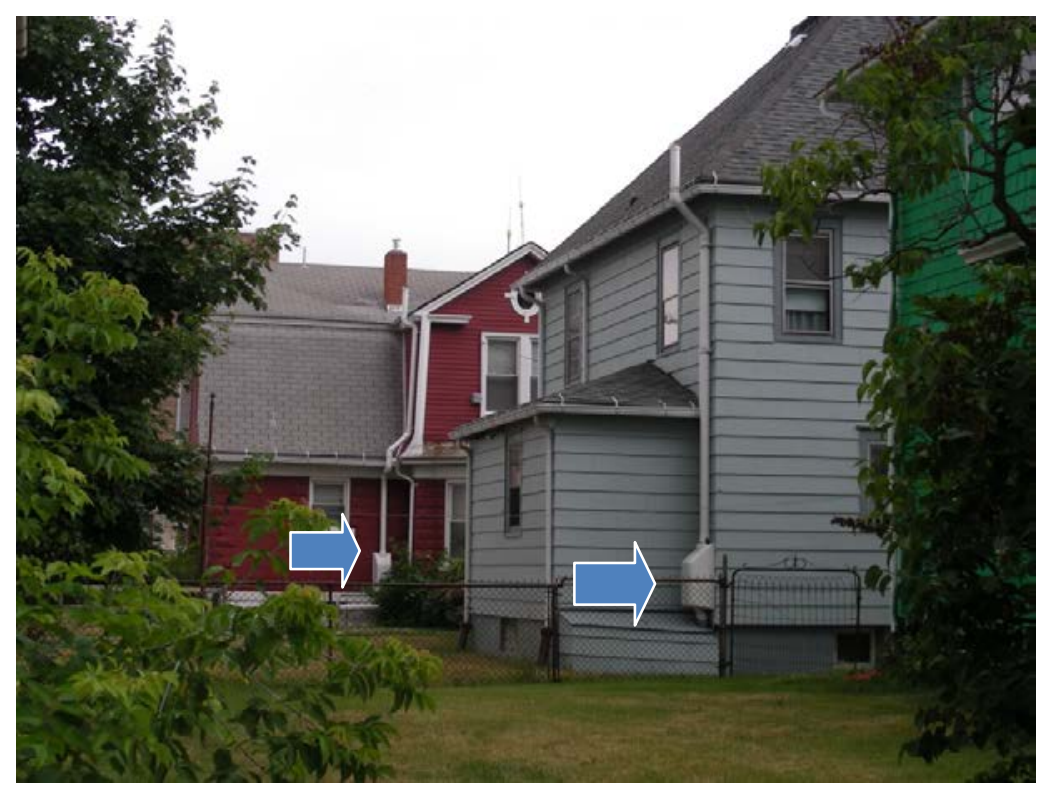

Figure 5: Vapor mitigation systems. Photo by author.

In some instances, there are chemicals that might affect the mitigation system design and exacerbate the risk scenario. For example, one resident brought me down to the basement of his home to show me an alarm system. Kevin said he didn't really know why he had this alarm on his system and was not sure if other people had it too. I told him I had never seen such a thing, but later found out that when potentially combustible vapors or those that may approach combustible concentrations are found during pre-mitigation sampling, it is common to install an alarm system on the mitigation device. After learning this, I called him to inform him of my findings. From what I could tell, he appreciated the call.

Vocal residents and community stakeholders see mitigation as a laudable protective decision. One vapor intrusion activist, who happens to also be a professor of geology and is a founding member of the New York State Vapor Intrusion Alliance, was also quoted in a stakeholders report saying that;

Under New York State's guidelines, if three homes are located on a toxic plume and the outer homes qualify for mitigation, VOC indoor levels in the middle home may not be high enough during a test to warrant mitigation. The middle homeowner has to suffer unacceptable anxiety during the period between tests to see if the levels may rise to the action level for mitigation. Therefore, to reduce anxiety of residents in a "monitor" phase, any home with vapor intrusion from an outside source should be mitigated...[He and his advocacy group] strongly supports blanket mitigation. All homes, schools and businesses on a known VOC plume should be mitigated to ensure against future intrusions of these unwanted toxins (Siegel 2007).

Active sub-slab depressurization systems (or what I am calling "vapor mitigation systems, or VMSs," because this is how they are most popularly understood by residents) are no doubt the "most widely applied and effective systems for vapor intrusion control" (ITRC 2007:50). They are "widely considered the most practical vapor intrusion mitigation strategy for most existing and new structures, including those with basement slabs or slab-on-grade foundations" (Siegel 2007:50; see also USEPA 1993). But, what do residents living in mitigated homes have to say about mitigation? How is mitigation experienced and grounded by real people living in an environment of mitigation? There is another world outside the vapor intrusion science and data supporting the argument that these systems are efficacious, and that they control intruding TCE vapors.

\section{Some ethnographic findings}

Those living outside the IBM-Endicott plume tend to misrepresent the experience of those living in it with mitigation. For example, I interviewed an Endicott resident who lives outside the plume. His home does not have a VMS, but this doesn't stop him from having an opinion about their efficacy. For him, they will be "working" in Endicott for a while; 
IBM is going to need to run those things for some time to come, it would appear. I mean they are working. I guess there is sometimes a question of what happens when the fan stops. I guess overall, these ventilation systems are necessary and keeping the people at least safer in their homes.

Like the DEC official mentioned earlier, this non-plume resident is sure that mitigation is working. This is not to say it is working for the mitigated, if "working" means theses technologies have in fact mitigated plumes residents' sense of risk and uncertainty. Rather than wiping away fear or extinguishing residents' risk perception, almost every resident with a system that I interviewed questioned or was perplexed by the possible risk of the toxic vapor being dispersed from the VMS pipe above the home. For Susan, who has lived in the plume since 1985, this uncertainty persists, despite her own sense that IBM made a good effort to do the right thing;

Well I thought it was good they came through and put these pipes in, although I do wonder where all this stuff is going. The pipes go to the top of the roof and then what? Where is it going? Its going right into the air. When our children were young and we would go outside, I could smell something. It really was quite a strong smell. At that time there was nothing about the pollution they were giving out, but I can remember the smoke stacks and everything. I don't really know what is going on. It just seems like a lot of it must be going into the air and we gotta be breathing it if it is going into the air.

In 2006, the US Agency for Toxic Substances and Disease Registry (ATSDR) conducted a study to address community concerns about ambient air issues. The ATSDR report, which analyzed historic emissions data from the former IBM facility (1987-1993), determined that three chemicals of concern-formaldehyde, methylene chloride, and tetrachloroethylene-needed further evaluation. ATSDR also found that TCE was a concern because of its presence in other environmental media (e.g., indoor air) and because of community concerns and information gathered during the evaluation process. ATSDR evaluated the possible health effects of past air exposures to these four contaminants and determined that these present "no apparent public health hazard" (ATSDR 2006:3). What this means is that adverse non-cancer health effects are not "expected," and that the likelihood of cancer resulting from an exposure during 1987-1993 was "very low to low" (or ranging from greater than one theoretical excess cancer case for every million persons exposed to less than one theoretical excess cancer case for every 10,000 persons exposed). ${ }^{7}$ ATSDR also evaluated the possible health effects of exposures to chemical mixtures, or the combination of multiple VOCs, finding that "adverse non-cancer health effects are not expected, and the cancer risk from the combined past air exposures to VOCs is considered to be low" (2006:3).

Despite ATSDR's study and the hard work put in to determine "low" risk, many plume residents are uncertain about the ambient air issue, and even contend that the VMSs are exacerbating the ambient air impact. One resident I interviewed added that it is kind of "strange" to assume that sucking vapors from underneath the home and releasing them above the home is a risk-free process, because "no one knows for sure;"

Well you know this system is taking the vapors out of the ground and it is the same system used for radon. It is the same idea. As the vapors come through the ground, instead of rising through the floor and whatever, they are sucked out into the air. On our property they put one on the crawl space and one in the basement. So there are two systems. Of course, that was one of the very first questions we asked. Ok, you are taking these vapors out of the ground and you are putting them in the air. Initially they told us 'Oh no, as soon as it hits the air it's immediately dissipated.' We thought 'well that sounds kinda strange'. So, now that is kinda up in the air. But assuming that system is working, we have not been tested. We requested to be tested, but they said 'No, it is not necessary because we are putting this system on everybody's house so you don't need it'. They never tested it in the first place, so how do we know it is working? No one knows for sure that by pumping this stuff into the air it really totally dissipates. We wonder 'Does it truly dissipate?' Then the discussion is back and forth. 'Now the air quality is bad because of it'. There has really been no conclusive test showing, that I know of, one way or the other.

Others explained this ambient air risk situation this way; "Here it is for me: All that stuff is being sucked up and then it is going into the air and everybody is breathing it. If there is no wind, ok, then what?" Or, "They

\footnotetext{
${ }^{7}$ The wide range in the order of magnitude here was an obvious source of frustration for activists I interviewed, primarily because they see an important difference between a risk ratio of 1 in a million and 1 in 10,000.
} 
say it dissipates, but who really knows." Another offered a technical solution: "It baffles me that they did not put carbon filters on the end of those things." When asked if she felt having a VMS installed would fix the problem, this old-timer responded;

Absolutely not. I'm a skeptic from way back. I'm Irish [laugh]. One thing I asked them was 'Ok, these things are venting it out. They are sucking it out from the basement, bringing it up through the pipe, and it goes out. Where does it go?' I mean it's out. It's the same stuff that was down there, but now it's here. Now they just throw it up.

Aside from this common critique of mitigation as a process of re-directing the TCE vapor, rather than really mitigating TCE from the plume environment, there is real lived confusion about risk mitigation, which Tom, a retired IBMer, summed up nicely;

Is it actually doing something? I guess it is because they wouldn't have wasted all their money, you know, putting them in if they weren't doing something. But, is the effects of it, you know, that good? We don't know. You know, at least if you saw something. It seems to me like any filtering system or whatever. If you saw, you know, residue, or if you saw a discoloration that would make you realize that something is coming out. But, we never see anything. There is no filter to see or nothing obvious. All we know is that that motor is running. I can figure that out for myself.

In addition to the "toxic uncertainty" (Auyero and Swistun 2009) illustrated here, which is an enduring problem in many other contaminated communities, there is also a hint of what Singer (2011) calls "toxic frustration." He explains that "Individuals who experience toxic frustration feel reasonably certain that the environment is unhealthy, point to the huge manufacturing plants and agribusinesses around them as the primary causes of their environmental suffering, but also believe there is not much they can do about it given their socioeconomic status and the unresponsiveness of the local or state government" (Singer 2011:158). I found that many residents share Tom's confusion about mitigation as an efficacious response to TCE contamination. In other words, confusion and frustration have not been mitigated by government actions, and plume residents feel reasonably certain that Endicott's plume environment is still unhealthy, even with all the remediation and mitigation efforts. ${ }^{8}$

\section{Mitigation as eyesore, noise, and symbol of property devaluation}

What I call the iatrogenesis of mitigation is really the unexpected consequences and concern that result from mitigation decisions, like the "blanket mitigation" decision responsible for over 500 VMSs. One iatrogenic effect of mitigation, for example, is that homeowners have to live with the "eyesore," as one informant put it, that comes with the VMS. For Shannon, "It looks ugly. That is why I had them put it behind the chimney. I didn't want people to see it." Others point out the noise that the VMS makes. The 90-watt motor runs 24 hours a day, seven days a week. The VMS makes a humming noise that can irritate residents. Shannon explained it this way;

That motor is loud. We hear it all through the night. I had to move my China closet because it was against the wall with the motor and the glass doors on it kept clanking. So, what is it doing? I can tell you the motors are running [Shannon has 2 VMS units on her home]. The noise reminds you it's there. I wasn't too happy about having a ventilator on my house because when they put it on the house the house hummed (see Figure 6).

Shannon even had IBM move it away from the wall so it was not flush against the exterior, which created an annoying rattle (Figure 6). She contemplated keeping it the way it was, because she like that it was hidden and tucked behind the chimney, but the noise eventually got to her. She tested her patience for a couple of months after it was installed and then called to have it moved after she realized she could not live with the noise. For her it came down to picking between an "eyesore and the noise." Shannon chose the former.

Some residents live with the noise and point out that it just starts to go away once you stop focusing on it. On the other hand, this trick only lasts so long. For example, plume resident of forty years, Lucille told me;

\footnotetext{
${ }^{8}$ I explore resident's emotional response to mitigation in more detail in Little 2012a.
} 
It vibrates and granted sometimes during the day you just get used to it and don't even hear it. But, at night, sometimes, and especially with all the kids gone, I will be sitting by myself and turn off the T.V. and be writing or something and I hear that noise. If I go up stairs and go in the room where I do my crafts late at night, that motor sound is there. You can hear that motor going.

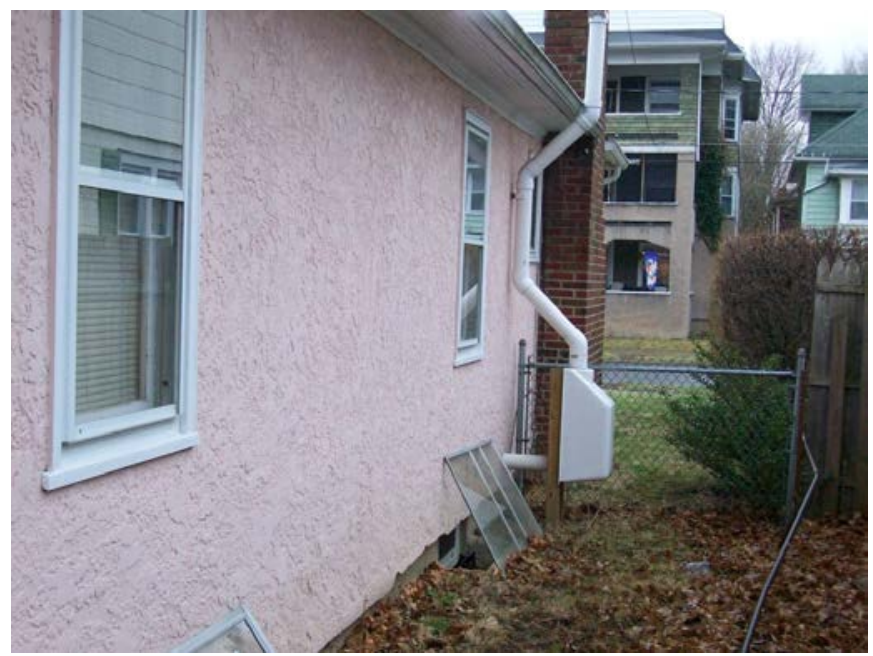

Figure 6. Shannon's "Noisy" VMS. Photo by P.Little, 2009.

In many ways, the VMS is like a mnemonic device, a constant reminder that IBM's TCE plume lives on, even when you would rather forget and wish it was mitigated and gone.

To correct the eyesore effect, some residents try to blend in the VMS by coloring the white piping (Figure 7). On a gloomy Saturday afternoon during one of my plume walks, I came across one resident who had put painting the VMS on his weekend "to do list." I ran into him just as he was finishing.

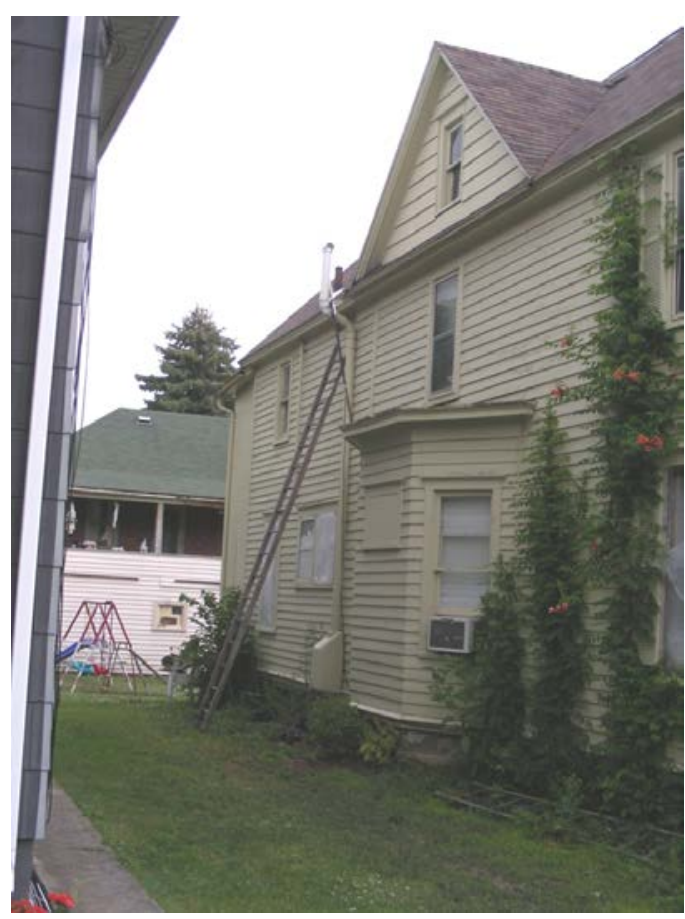

Figure 7. Blending in the VMS. Photo by author, 2008. 
We chatted briefly in his driveway, where he explained that "the white looked ugly" and that he was also painting it because he was planning to try and sell the house in the next couple of months.

Communities impacted by vapor intrusion tend to worry about two primary issues: health impacts and property devaluation. The later is of particular interest because even efforts to mitigate vapor intrusion mark a structure as a source or site of vapor intrusion, even if the home has been determined a "mitigated" structure. Mitigation systems, like the presence of contamination itself, leads to "...the inversion of [the] home"... "The meaning of home as haven from a complex society is inverted by toxic exposure" (Edelstein 2004:93). ${ }^{9}$ The same can be said even when houses have been mitigated. Recent social complexities and crises have contributed to this process of inversion. For example, the meaning of home as a good, lifelong investment has been inverted, due to the real estate market crash of 2008, which was in full bloom just as I began my dissertation fieldwork in the summer. While one newcomer to the community told me that her realtor had told her that the VMS was a "home improvement," this did not seem to come up in my interviews with plume residents. Instead, homeowners seem to be collectively concerned about property devaluation and frustrated about paying taxes on a house tainted and devalued by IBM TCE contamination. What follows is just a snap-shot of some of the narratives I collected on this theme.

The majority of homeowners who responded to my survey $(n=50)$ either said they were "very concerned" (29, or 58\%) or "concerned" (13, or $26 \%$ ) that the IBM contamination had depreciated the value of their home. Because Endicott is a village within the town of Union, residents are required to pay village taxes, in addition to state and federal taxes. Many of homeowners in the plume contested the property taxes they owe Endicott. In fact, many complained that residents pay too much. In general, most of these informants felt they should not be paying the same property taxes that non-plume residents pay. Much of the taxation talk turns to a critique of IBM-sometimes explicit, sometimes implicit—and IBM's abandonment of Endicott, leaving it with a massively reduced tax base. In this way, the connections between property devaluation, taxation, and IBM deindustrialization were sharply defined. In the words of one plume resident, retired IBMer, and proprietor: "The whole village just took a really hard hit from all of this. With the taxes and everything, it's just a downward spiral."

One former IBMer and village board member empathized with plume residents, arguing that IBM should have offered them more than they did to cover the property value damages, damages that TCE mitigation efforts and technologies don't get rid of;

Maybe IBM should have offered more than $\$ 10,000^{10}$ because of the property devaluation issue. ...It's an enormous problem. People who live in the plume have a problem. Even if the property looks like it is going fine and the mitigation system is working fine and there is nothing wrong with the property, just the fact that they live in the plume is killing the value of their property. If the plume wasn't there, everybody would be fine. They got screwed. A lot of people packed up their bags and moved out of that area. Some people can't afford to leave or can't afford to take the loss of selling their home for nothing and moving someplace else. A lot of people are just stuck.

Being "stuck" in the "mitigated" plume as a homeowner is a serious problem that surfaced in one of my interviews with a couple who have been living in Endicott since the mid 1980s. Their story and situation is not unlike that of other homeowners living in mitigated homes with declining value;

Lou: The value of our house has gone down the tubes. You know, we tried to get it appraised and we couldn't get it appraised for what we bought it for... So I think one of the things that really bothered me is the property value. Even when we tried to get the house appraised we knew that we had probably put about $\$ 20,000$ into remodeling, changing and replacing all the windows, we built this back deck, and yet when they come they can't even appraise it for as much as we paid for it.

Tiffany: They just turned us down outright. They could not give us enough for the mortgage and finally FHA did for \$1,500 hundred dollars more than we paid for it 22 years ago. I feel and I think my neighbors feel too that, I mean, because of this there is no way we can sell our homes for what we think they are worth. They will laugh at that too. They will say 'Everybody

\footnotetext{
${ }^{9}$ Edelstein (2004) draws on examples from several Superfund sites nationwide, including Love Canal (New York), Times Beach (Missouri), Legler (New Jersey), and Triana (Alabama) to demonstrate how not only how the home becomes a prison once determined a toxic living space, but also a major source of financial loss, which in turn only exacerbates feelings of distress.

${ }^{10}$ IBM did offer homeowners in the plume $\$ 10,000$, which they determined was about $8 \%$ of the property value lost as a result of the TCE contamination. All of my informants wonder how they came up with this figure.
} 
thinks their house is worth more'. I can show you bills. We put in $\$ 20,000$ and you mean to tell me, you know, that I only appreciated $\$ 1,500$ in over 20 years. I mean, so now its kinda of a joke and I think a lot of my neighbors feel the same way. You know, somebody will say 'Where do you live?' 'On the avenue in the plume' [laugh]. I mean, come on. Our property value has depreciated so much.

Lou: Yeah, so it's got a real negative connotation because of this area. You know, anybody that hears were you live it 'Aw, you guys live over in the IBM spill.' Now we have not tried to sell our house, but with the way the appraisal process went. Well we are just lucky to get a refinance, but ah, it took some real effort on our part... Unfortunately, you know, it's like the damage has been done and I don't know if, as far as property value goes, people will ever want to buy a house in an area that they know has been polluted. They know they can just buy elsewhere. Here it is a question mark. We have been here 20 years and things have just gone downhill around here. Can we blame this all on the TCE? If I did sell, I would be taking a huge loss. Two houses on this side of the street have not been able to sell and one 4 bedroom house across the street sold for $\$ 38,000$. That wouldn't even cover my mortgage if I had to sell at that price. I wish IBM would just buy my house, but I don't see that happening. Will IBM step up to the plate and really do that? Well, IBM did offer that $\$ 10,000$. With that they are saying that they are paying for the damages to the property value. Had I known at the time that it was not taxable I probably would have taken it because my problem is that my son had just started his second year of college when this happened. If I took the money, it would have increased our reported income and so would have impacted my son's ability to get financial aid. Also at that time I was just starting to collect social security, so I was in that magical 62-65 age. So anything over \$10,000 a year I have to give back. It's like for every \$2 dollars you make you have to give back $\$ 1$. I don't know if I would have taken it or not anyway, but I didn't.

Like many plume residents who were offered IBM's $\$ 10,000$ compensation for property damages, Tiffany and Lou turned it down, even though they might not have, if they known it was not taxable. Of the homeowners I surveyed who were offered IBM's $\$ 10,000$ settlement $(n=38)$, only 14 , or $37 \%$ took it, and the majority (24, or $63 \%)$ declined the offer.

Many homeowners are simply frustrated because they feel it is pointless to invest anything into there home, even though they may want to upgrade a kitchen or bathroom. One couple I interviewed had this to say;

Don: Our main concern is the property value... I certainly think the property value has gone down here because we are right here in the middle of this crap. That is what I call it. I call the plume the crap...We bought this home in 1970 for $\$ 18,000$. We put money into it, but we will never get out of it what we put into it...We won't do anymore upgrading to the house. It's just not worth it. I won't do nothing.

Mary: We just don't feel it makes any sense to put any more money into this house.

Don: Nothing. She wants a new kitchen, but we are not going to get involved in that.

The above narratives illustrate some of the lived experiences of the "inversion" (Edelstein 2004) or "subversion" (Douglas 1993) of the home thesis. Frustration and insecurity persist amid IBM and NYDEC remediation and mitigation efforts. No matter how much the plume shrinks as a result of the NYDEC's aggressive groundwater remediation project or how technically efficacious mitigation is as a strategy to reduce TCE concentrations in indoor air, the fact is that property devaluation, the "empire of risk" (Ferguson 2009) resulting from the real estate market crash and the financial crisis of 2008-2009, and national and global social and economic insecurity seem to be as intrusive and present as the risks of TCE vapor intrusion. As Singer rightfully points out "toxic frustration does not exist in isolation from other aspects of social experience but, rather, is a component of a wider and deeper sense of enduring disappointment" (Singer 2011:158). The above narratives certainly remind us of this political ecological fact.

\section{Renters, tenant notification, and the politics of knowledge}

A critical perspective on mitigation loses strength and utility if it does not attend to people left out of the debate, and for the purposes of this article, that group of people are renters living in the plume. An almost unspoken issue at the local level in Endicotts' plume is the politics of understanding and knowledge between homeowners and renters, the later group making up a large portion of the IBM-Endicott plume population. State Assemblywomen Donna Lupardo was instrumental in getting New York's Governor David Patterson to sign into law the Tenant Notification Bill (A10952-B) requiring landlords to notify tenants of the results of 
environmental testing. But this law is, to my knowledge, rarely if ever enforced, leaving renters in the community unaware of the plume they live, nor what the VMS on their rental property is doing.

One of the more statistically significant results of my survey of plume residents was that owners and renters living in homes with mitigation systems have differing levels of understanding of the VMS. When asked to rank the survey question "I understand how the VMS Works", based on a scale from 1 to 5, with 1 being "Strongly agree" and 5 being "Strongly disagree," I found a significant difference between renters and owners $(\mathrm{p}=.000)$ using a Mann-Whitney test (see Table 1$)$. Renters were much more likely to express that they did not understand how the VMS works.

\begin{tabular}{|c|c|c|c|c|}
\hline Owners & $\underline{\mathbf{N}}$ & $\underline{\text { Mean Rank }}$ & $\underline{\text { Std. Dev. }}$ & Asymp. Sig \\
\cline { 1 - 2 } Renters & 24 & 47.17 & & \\
& & & & .220 \\
\end{tabular}

Table 1: "I understand how the VMS Works" Renters vs. Owners

According to the Interstate Technology and Regulatory Council (ITRC), community stakeholders at vapor intrusion sites have demanded that "mitigation techniques...should include a long-term monitoring plan and a contingency plan" (ITRC 2007:A-3). My community survey results indicate that what also ought to be included in this "monitoring" plan is a greater effort to inform renters about vapor intrusion mitigation.

Homeowners tend to dominate the pool of "community stakeholders" involved in vapor intrusion debates, and the renter perspective and experience gets lost. We should not assume that the more people know about mitigation the more they trust it, but instead demand to know more about how people make sense of their mitigation situation. This making sense needs to be demonstrated, not assumed. Furthermore, a common understanding among activists and regulators in vapor intrusion debates is that the level of indoor air contamination associated with a decision to install mitigation systems has varied among sites and sometimes even at the same site, which in turn often raises concerns among the public regarding the safety and fairness of mitigation decisions.

If tenant notification laws are in fact an option to attain greater fairness-which I think they are-we need to better understand how to share knowledge about the risks of vapor intrusion, mitigation, and even the law of tenant notification at the local level, and determine who is ultimately responsible for this work. Public meetings and flyers can work, but according to my survey results, renters in the plume do not seem to be showing up to public meetings on the IBM-Endicott pollution issue. In fact, I found that while 37 out of 50 homeowners surveyed $(74 \%)$ had attended at least one public meeting, only 5 out of 31 renters $(16 \%)$ had done so. I suspect that one of the major reasons for a low turnout is because renters have not "invested" in the plume, as homeowners have, and so keeping up to speed on the progress of the remediation effort-the usual focus of the public meetings - is of little interest. Again, this is just speculation, but it is clear to me at this point in the history of the IBM-Endicott debacle that we need to better understand the differences between renters and owners to better grasp the unfolding political ecology of risk and mitigation, especially since many of my informants claimed that there is a rising "welfare" population in Endicott. ${ }^{\text {g }}$

\section{Toward a political ecology of mitigation in/of risk society}

The ubiquitous presence of TCE contamination and vapor mitigation systems on the Endicott landscape has defined the community, in many ways, as a "contaminated community" (Edelstein 2004) in general and as a 'mitigated community' in particular. Whether or not residents occupying mitigated buildings share similar political views or are of similar socio-economic status, the presence of these mitigation systems establishes a kind of foundation or starting point for a new, shared, and often stigmatized, identity. As described in more detail below, I argue that residents living with TCE contamination and vapor mitigation systems also inhabit a landscape of political ecological processes that influence local experiences with toxics mitigation. The political ecology of mitigation (or PEM) perspective proposed here is strengthened by a committed effort to use ethnographic description to ground local mitigation discourse and make the experience of Endicotts' mitigated citizens more audible and meaningful.

The PEM perspective assumes that the mitigation decision-making system-a system primarily dominated by a State apparatus composed of scientists, experts, and regulators-is important for understanding the functionality of risk decisions for communities faced with, for example, vapor intrusion

\footnotetext{
${ }^{11}$ I explore local interpretations of environmental justice politics in Little 2012b.
} 
risk. In fact, the most important contribution of the PEM perspective in Endicott and other communities coping with vapor intrusion, is its ability to demonstrate and intensify our understanding of how public mitigation decisions can expose broader "risk society" question (Beck 1992; Giddens 1990). These "risk society" features include, but are not limited to, the contentious and pervasive use of toxic substances in the late modern era, the stigmatization experienced by citizens struggling or coping with 'plume living', the emergence of corporate environmentalism and reconfiguration of corporate responsibility, ${ }^{2}$ and the sense of community "corrosion" experienced by postindustrial subjects coping with the dual threat of deindustrialization and contamination (Erikson 1991, 1994; Freudenburg and Jones 1991; Kroll-Smith and Couch 1989).

The risk society unfolding in Endicott, is a reflection of capitalism's "innovative self-destruction" (Berman 1982:98) and its scientific efforts to manage toxic externalities. Assessments of environmental public health policies, structures, and institutions cannot, of course, answer all of the important social questions surrounding vapor intrusion mitigation, but the PEM contribution is indispensable to the comprehensive study of contaminated communities under remediation and mitigation. The PEM perspective attends to the lived experience of mitigated citizens and therefore grounds the vapor intrusion debate in society rather than in science and the technologies of risk management.

One major PEM question explored in this article was to what extent the decision to mitigate TCE vapors successfully addresses citizen concerns and informs their perceptions of vapor intrusion risk? My research illustrates great uncertainty and confusion on this matter and therefore begs the following question: Is a more socially sensitive and reflexive mitigation process possible in contaminated communities? Ultimately, the PEM is a theory and practice committed to enhancing and encouraging the democratization of toxics risk debates. This highlights the "political" in my PEM perspective. PEM, like other political ecology and political economy work, is interventionist and critical of closed techno-scientific risk decision-making approaches, even though it can value these forms of knowledge and expertise at the same time. It wishes to foster a decision-making environment based on expert and civic epistemology.

Moreover, while mitigation politics are the primary concern of the PEM perspective, it is also about looking beyond mitigation by engaging its aftermath. Post-mitigation issues are as critical as decisions to mitigate. PEM insists on understanding how power-knowledge persists after mitigation, not just during mitigation decision making. In the case, once the VMS is installed, mitigation becomes a matter of social experience. People live in mitigated homes in a mitigated landscape. They have things to say about this mitigated lifestyle, about what it means to live "in the plume" and with a vapor mitigation system "controlling" vapor intrusion risk. The PEM perspective turns mitigation into social critique, a decision that is socially constituted, experienced, and negotiated. It acknowledges the effect of mitigation on people and their converging and diverging ways of experiencing or sensing the riskscape, or more appropriately, the mitigationscape. They are coping with invisibility, imperceptibility, and doubt, and this complicates their sense-making and perception of risk and mitigation. In a Latourian sense, political ecology exposes the complexity of associations at the same time that it resists unfounded demarcations (e.g., between nature and society, or contaminated environments and mitigated environments). PEM grapples with the messy intersection of environmental health risk, mitigation, uncertainty, and embodied subjectivity. Ethnographic description is employed to make sense of these intersecting PEM themes.

My PEM perspective aims to challenge and move beyond the binary naturalistic-culturalistic view of the landscape, a move which in some ways attends to what Ingold (2000:189) refers to as the "dwelling perspective." This perspective, inspired by the phenomenology of Maurice Merleau-Ponty, engages the "temporality of the landscape" and intensifies anthropological discussions of the mitigated landscape: "As the familiar domain of our dwelling, [the landscape] is with us, not against us, but it is no less real for that. And through living in it, the landscape becomes part of us, just as we are a part of it" (Ingold 2000:191). The mitigated landscape represents more than "a neutral, external backdrop to human activities" nor "a particular cognitive or symbolic ordering of space" (2000:189); Endicott is a landscape of people "dwelling" and living with contamination, mitigation, and valid concerns about environmental health risk. ${ }^{13}$ Vapor mitigation systems are not just "on" downtown buildings or "part of" the Endicott landscape; they are lived with, and integral to lived experience. There is a difference. These mitigation technologies are not in the "background," nor in the "back" of the mind of plume residents. It seems impossible or unrealistic to untangle local experiences of vapor intrusion, mitigation, property devaluation, and public health risk. None of these rest in

\footnotetext{
12 This corporate social and environmental responsibility message is summed up by the words of IBM spokesperson, Michael Maloney; "None of it was done intentionally, but we are still sticking around to take care of it...We feel obligated legally, ethically, and morally...We are not going anywhere" (Gramza 2009: A-7).

13 The main contaminant of public health concern is trichloroethylene (TCE), a known cancer-causing toxic substance that has recently been determined by numerous epidemiological studies to be "carcinogenic to humans by all routes of exposure and poses a potential human health hazard for noncancer toxicity to the central nervous system, kidney, liver, immune system, male reproductive system, and the developing embryo/fetus" (Chiu et al 2013:303).
} 
the "background" when plume residents talk about plume living and their experiences of health and environmental suffering (Singer 2011; Auyero and Swistun 2009).

\section{Another case of deterritoriality and reterritoriality?}

The PEM unfolding in IBM's birthplace also invokes a closer look at the processes of deterritoriality and reterritoriality, concepts which emerged in the works of Deuluze and Guattari (1987). These concepts theoretically ground residents' critical narratives of IBM deindustrialization and local critiques of TCE mitigation efforts. Kuletz (1998) has used the concept of deterritoriality in her study of nuclear testing and contamination in the western US to theorize "zones of sacrifice;"

Once made visible, the zones of sacrifice that comprise these local landscapes can begin to be pieced together to reveal regional, national, and even global patterns of deterritoriality - the loss of commitment by modern nation-states (and even the international community) to particular lands or regions (Kuletz 1998:7, her emphasis).

Another major player in the game of deterritoriality is the multinational corporation, with the power to settle, accumulate capital, and abandon spaces of production. Whether intended or not, Endicott was and is an IBM "sacrifice zone" (Lerner 2010). It is a place once home to a committed IBM workforce and a place nicknamed "Main Street IBM." More than three hundred acres (121 ha) of downtown Endicott are marked by a plethora of vapor mitigation systems. In this sense, IBM deterritorialization has been replaced by scientific and mitigation decisions orchestrated by state agencies, that have, in effect, reterritorialized the downtown. State and federal experts and regulators (e.g. the New York State Department of Environmental Conservations and Department of Health, and the US Agency for Toxic Substances and Disease Registry and the National Institutes of Occupational Safety and Health) figure in this "new Endicott." There is really nothing unusual about this shift. This "new Endicott" is the common outcome of capitalism's "restless formation and reformation of geographical landscapes," as described by David Harvey;

Capitalism perpetually strives...to create a social and physical landscape in its own image and requisite to its own needs at a particular point in time, only just as certainly to undermine, disrupt and even destroy that landscape at a later point in time. The inner contradictions of capitalism are expressed through the restless formation and reformation of geographical landscapes. This is the tune to which the historical geography of capitalism must dance without ease (Harvey 1985:150).

Deterritoriality and reterritoriality are useful concepts to draw on to navigate its shift from a site of successful IBM production to a site of contentious TCE contamination and mitigation. TCE contamination and TCE mitigation are features/markers of Endicotts' visual and environmental reformation. In fact, Endicott Interconnect Technologies Inc. still manufacture in the town, but on a lesser scale than IBM. Shifts in the geographical landscape over time have social implications in that they potentiate a change or a reconfiguration of citizens' views on risk management.

\section{Exposing the political nature of mitigation}

The PEM perspective also sheds light on the vibrant "political nature" of TCE mitigation (Meyer 2001; Bennett 2010). It is a critical socio-environmental theory of risk mitigation, grounding the discussion of mitigation politics in local discourse.

Research attentive to the broader interface of contamination and community is pertinent to PEM. Environmental psychologist Michael Edelstein has identified "contaminated communities," including radon risk, and what he terms the "inversion of home" for residents living in toxic environments (Edelstein 1986). Edelstein and Makofske (1998:315) argue for a more integrative ecological theory of the home;

[e]cological theory tells us that we are not subject to bounded conditions. A preventative view toward health, based on environmental vigilance, will similarly need to understand risk in a cumulative, interactive fashion. Our total lack of preparation for looking at cumulative, interactive conditions is readily evident in the limits to our understanding of homes. The focus on the whole house, rather than just specialized and isolated issues such as radon [or other VOCs like TCE and the vapor intrusion problem in general], mirrors the larger need to examine the whole earth, rather than just localized and immediately visible environmental degradation (Edelstein and Makofske 1998: 315).

Oddly enough, this "integrative" and holistic (or "big picture") approach misses the understanding of the home as a space of equity, as symbol of life-long investment, and, as a symbolic space of value that becomes the focus of residential property devaluation debates. It has been argued that the home in contaminated communities needs to be rethought in ecological terms to better grasp "the big picture": "Integrative thinking about buildings is still rare. There is scant attention to the home as an ecological 
system..." (Edelstein and Makofske 1998:315), although Mary Douglas's (1993) contention was that the "...home is a fragile system, easy to subvert" (Douglas 1993:275).

The mitigated home (Figure 8) is a symbol, a space, of political ecological dispute invoked by layexpert relations and knowledge politics. Edlestein (2004:161) draws on Illich (1977), showing how "toxic victims become 'disabled'." In effect, contamination disputes often lead to a normative "life context" or situation whereby citizens become "disabled" and the experience of contamination is "disabling" for it exposes unexpected, unplanned dependency on expertise, and dependency on 'others' (e.g., government scientists and attorneys) to navigate toxic disruption;

With the discovery and announcement of contamination, toxic victims suddenly find themselves in a complex institutional context made up of the various local, state, and federal agencies having jurisdiction over their contamination incident. This is an unfamiliar life context for most people, one for which they lack experience. Their lives are essentially captured by agencies on which they become dependent for clarification and assistance. Technical experts and lawyers, from government and industry, now dictate the terms defining such core issues as safety and risk and whether they will be helped to find safe water or to relocate (Edelstein 2004:161).

Contamination disputes rarely lead to clarity and clean or satisfactory communication between actors, and problems like vapor intrusion seem to exacerbate this "double bind" effect, perhaps because of the complexities and ambiguities of the science of vapor intrusion and it's regulation and mitigation. This creates a kind of "friction" (Tsing 2005), a term that helps remind us "of the importance of interaction in defining movement, cultural form, and agency" (Tsing 2005:6, my emphasis). Endicott residents are dealing with multiple points of friction and struggle that mitigation cannot resolve. For many residents I interviewed, Endicott has become the "sink" (Tarr 1996) of IBM pollution and the mitigation effort is likened to, according to one resident, "a band-aid on cancer." Local pollution control, remediation, and mitigation efforts, according to many residents, have all resulted in a pattern of "retrofits and technological fixes" (Tarr 1996:29). Moreover, the deployment of technology to repair the toxic legacy of IBM production exemplifies a critical social feedback loop, or what Ulrich Beck would call "reflexive modernization" (Beck 1992). Mitigation is perhaps a reminder of "friction" (Tsing 2005) rather than simply a technology of risk response, management, or control.

\section{Conclusions}

Political ecology is a critical framework that refuses to divorce society, politics, and mitigation. Instead, it mingles these domains. It is not necessarily aiming to shame experts in the field of vapor intrusion and risk mitigation. Instead, it is about honoring the "dynamic biosocial complexes" (Castree 2007: 283, emphasis in original) and the transboundary nature of toxics substances, repair strategies, and the social life of risk and risk mitigation.

My goal in this article has been to open up a new terrain for the political ecology of toxic environments in general, and in particular contamination repair in a risk society. I have conducted ethnographic work into mitigation and the micropolitics of risk mitigation. Cleanup is often the first goal of grassroots organizations coping with toxics contamination. But, what is left un-mitigated in sites of statecorporate risk mitigation? The answer: a lot. Respondents did not feel they are living a life of less risk.

Mitigation has played a minor role in the explosive field of cognitive risk perception research (see Slovic 2011, 1992, 1987). One researcher in this field has contended that;

Demand for mitigation is a concept calling for further analysis. Who should mitigate, and who should pay? Is mitigation at all possible? How do moral aspects enter the picture - is, for example, the cost of mitigation to be carried by the perpetrator who created the risk and perhaps made some economic profit out of it? These are questions for further research (Sjöberg 1999:141).

Advancing this line of research without strong footing in the co-mingling fields of political ecology and risk society misses the complex social terrain of mitigation that is lived and experienced by active subjects. Some questions for further research that I propose are the following:

- What are the social dimensions of toxics mitigation?

- How are mitigation decisions made and by whom?

- How is mitigation experienced by the mitigated?

- How or why does mitigation fail to restore trust?

- Why do expert-public relations remain contentious after mitigation? 


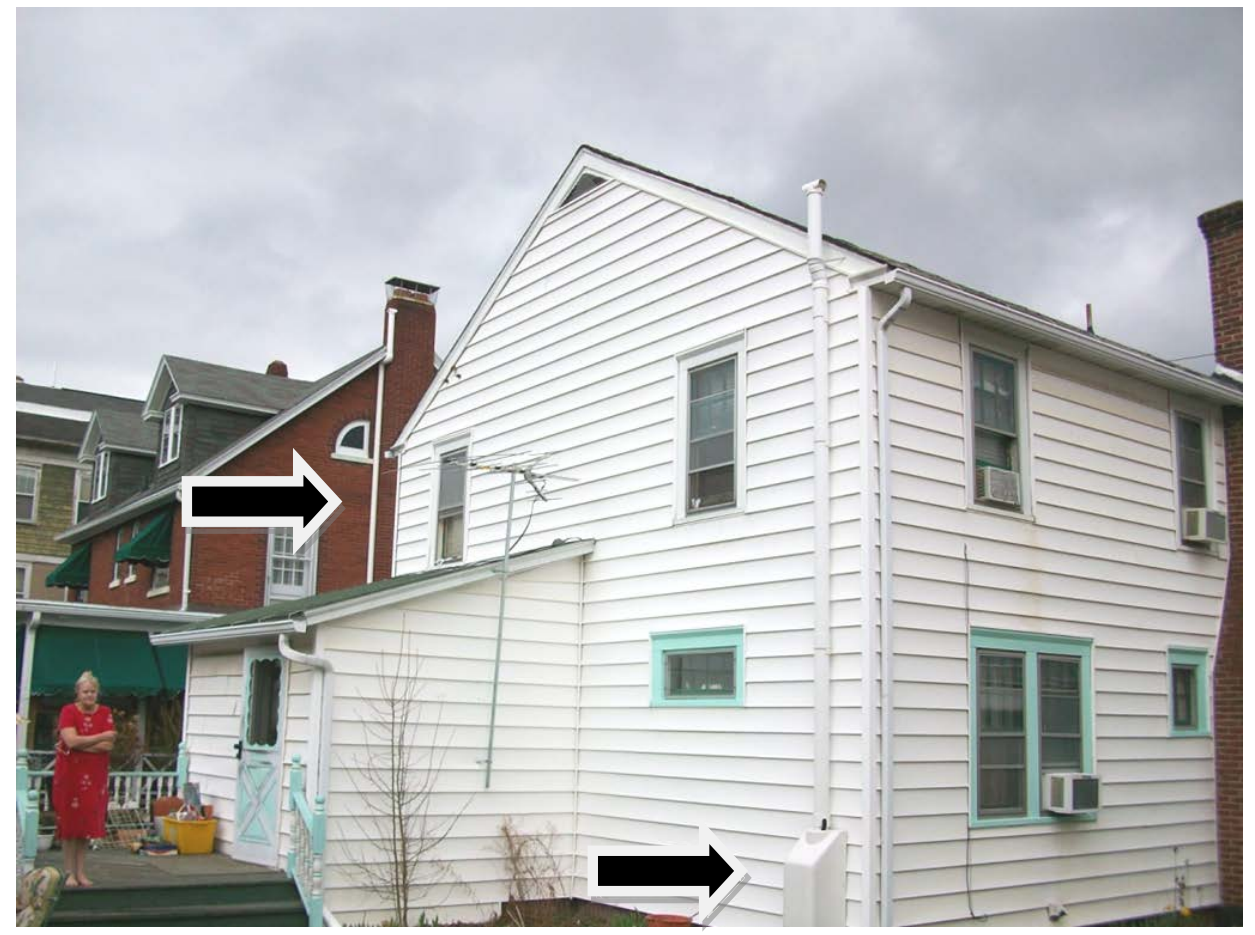

Figure 8: Mitigation systems, a dubious "home improvement." Photo by author.

To really engage these questions, PEM research and action needs to uncover deeper power dynamics. Demand for corporate social responsibility, the repair of industrial decay, and making contaminated communities like Endicott "nice" places to live again, are matters of concern that go far beyond TCE mitigation. But, how political ought the political ecology of mitigation proposed in this article be? I don't have a ready-made answer to this critical question, but recent observations of the actual politicization of political ecology are worth noting, especially the work of Peter Walker (2007). Walker asks;

...how much practical difference does "political ecology actually make? What might be the obstacles to a more constructively engaged political ecology - to a more fully political political ecology? These are the questions that this essay raises briefly, but does not pretend to answer in any substantial way. Rather, it is hoped and believed that these questions will be discussed at length in future venues. It seems generally agreed that the 'liberatory potential' of this field is, to a large degree, its raison d'etre - even if it is not fully realized in practice. If so, even the possibility that political ecology, with all its enormous intellectual strides, might be largely deskbound, and, ultimately, apolitical and powerless in practice merits considering these questions seriously. Clear guidelines for what constitutes ethical political ecology practices and power are needed. (Walker 2007:364, emphasis in original)

For the purposes of this article, attempts to bring "mitigation" into political ecologies of contaminated environments might lead to or expose the need for more "ethical" strategies of toxics mitigation, strategies or practices that avoid treating it as just another cost-effective technoscientific decision that ends with the installment of a ventilation system. As the ethnographic data discussed here illustrates, mitigation is more than this. The social landscape of toxic struggle is complex and the PEM perspective helps expose the social disorder of orderly schemes of toxics repair. Mitigation, under this theoretical optic, perpetuates a form of control and domination, even if mitigation technologies really do "soften" the risk situation.

In closing, it is worth considering the ethical parallels that connect efforts to know what exactly constitutes ethical mitigation and what it means to develop and commit to ethical political ecology practice and power. To return to the active ingredient in Eric Wolf's work, these power relations and the terrain of political ecology itself needs to be demonstrated, not assumed. The same goes for investigations of "neoliberal ecologies" (Castree 2007) attempting to explicate conditions and practices such as toxics mitigation and other forms of crises or disaster repair emerging in contemporary neoliberal environments like Endicott, New York, the celebrated birthplace and unfortunate contamination zone of one of the world's most powerful multinational information technology firms. 


\section{References}

Allen, B. 2003. Uneasy alchemy: citizens and experts in Louisiana's chemical corridor dispute. Cambridge: MIT Press.

Auyero, J. and Débora S. 2009. Flammable: environmental suffering in an Argentine shantytown. Oxford: Oxford University Press.

Beck, U. 2006. Living in the world risk society. Economy and Society 35(3): 239-345.

- $\quad$ 1999. World risk society. Cambridge: Polity Press.

Bennett, Jane. 2010. Vibrant matter: a political ecology of things. Durham and London: Duke University Press.

Berman, M. 1982. All that is solid melts into air: the experience of modernity. New York: Penguin.

Boggard, W.C. 1988. Bringing social theory to hazards research: conditions and consequences of the mitigation of environmental hazards. Sociological Perspectives 31(2):147-168.

Bourdieu, P. 1977. Outline of a theory of practice. Richard Nice, trans. Cambridge: Cambridge University Press.

Brenner, N. and N. Theodore. 2007. Neoliberalism and the regulation of "environment". In Heynen, N. J. McCarthy, S. Prudham, and P. Robbins (eds.) Neoliberal environments. London and New York: Routledge. Pp.153-159.

Caplan, P. (ed.) 2000. Risk revisited. London: Pluto Press.

Castree, N. 2007. Neoliberal ecologies. In Heynen, N., J. McCarthy, S. Prudham, and P. Robbins (eds.) Neoliberal environments. London and New York: Routledge. Pp. 281-286.

Checker, M. 2005. Polluted promises: environmental racism and the search for justice in a southern town. New York: New York University Press.

Chiu, W.A. et al. 2013. Human health effects of trichloroethylene: key findings and scientific issues. Environmental health perspectives 121(3):303-311.

Deleuze, Gilles and Félix Guattari. 1987. A thousand plateaus: capitalism and schizophrenia. Brian Massumi, trans. Minneapolis: University of Minnesota Press.

Douglas, M. 1993. The idea of a home: a kind of space. In Mack A. (ed.) Home: a place in the world. New York and London: New York University Press. Pp.261-281.

Edelstein, M.R. 2004. Contaminated communities: coping with residential toxic exposure. Boulder: Westview.

- $\quad$ 1986. Toxic exposure and the inversion of home. Journal of Architecture and Planning Research 3: 237-251.

Edelstein, M.R., and Makofske W.J. 1998. Radon's deadly daughters: science, environmental policy, and the politics of risk. London: Rowman and Littlefield.

Erikson, K. 1994. A new species of trouble: explorations in disaster, trauma, and community. New York: Norton.

- 1991 A new species of trouble. In Crouch S. and J.S. Kroll-Smith (eds.) Communities at risk: community responses to technological disasters. New York: Peter Lang. Pp.12-29.

Freudenburg, W.R. and T. Jones. 1991. Attitudes and stress in the presence of technological risk: a test of the Supreme Court hypothesis. Social Forces 69(4):1143-1168.

Giddens, A. 1990. The consequences of modernity. Cambridge: Polity Press.

Gramza, J. 2009. Life in the plume: IBM's pollution haunts a village. The Post-Standard, January 11.

Harvey, D. 1985. The geopolitics of capitalism. In D. Gregory and J.Urry (eds.) Social relations and spatial structures. London: Macmillan. Pp.128-163

Henke, C.R. 2008. Cultivating science, harvesting power: science and industrial agriculture in California. Cambridge, MA: MIT Press.

Illich, I. 1977. Disabling professions. In Illich et al. (eds.) Disabling professions. London: Marion Boyers. Pp11-40.

Inglod, T. 2000. The perception of the environment: essays in livelihood, dwelling and skill. London and New York: Routledge.

Interstate Technology and Regulatory Council. 2007. Vapor intrusion pathway: a practical guideline. ITRC Technical and Regulatory Guidance Document. January.

Kroll-Smith, J.S., and S. Couch. 1989. The real disaster is above ground: a mine fire and social conflict. Lexington: University of Kentucky Press.

Kuletz, V.L. 1998. The tainted desert: environmental ruin in the American West. New York and London: Routledge.

Lerner, S.D. 2010. Sacrifice zones: the front lines of toxic chemical exposure in the United States. Cambridge: MIT Press. 
Little, P.C. 2012a. Another angle on pollution experience: toward an emotional ecology of risk mitigation. Ethos 40(4): 431-452.

- 2012b. Environmental justice discomfort and disconnect in IBM's tainted birthplace: micropolitical ecology perspective. Capitalism, Nature, Socialism 23(2): 92-109.

- $\quad$ 2010. "Instead of tumbleweed, we have mitigation systems": an ethnography of toxics risk, mitigation, and advocacy in IBM's deindustrialized birthplace. Ph.D. dissertation. Department of Anthropology, Oregon State University.

- 2009. Negotiating community engagement and science in the federal environmental public health sector. Medical Anthropology Quarterly 23(2): 94-118.

Meyer, J.M. 2001. Political nature: environmentalism and the interpretation of western thought. Cambridge, MA: MIT Press.

Paulson S., L.L. Gezon, and M.J. Watts. 2003. Locating the political in political ecology: an introduction. Human Organization 62(3): 205-217.

Siegel, L. 2009. A stakeholder's guide to vapor intrusion. Center for Public Environmental Oversight. November.

- $\quad$ 2008. Report on the national stakeholders' panel on vapor intrusion. Center for Public Environmental Oversight. San Diego, CA. March 12.

- 2007. Report on the Albany vapor intrusion activists' meeting. Center for Public Environmental Oversight. November.

Singer, M. 2011. Down cancer alley: the lived experience of health and environmental suffering in Louisiana's Chemical Corridor. Medical Anthropology Quarterly 25(2):141-163.

Sjöberg, L. 1999. Consequences of perceived risk: demand for mitigation. Journal of Risk Research 2(2): 129-149.

Slovic, P. 2001. The perception of risk. London: Earthscan.

- $\quad$ 1992. Perception of risk: reflections on the psychometric paradigm. In Golding D. and Krimsky S. (eds.) Theories of risk. London: Praeger. Pp.117-152.

- $\quad$ 1987. Perception of risk. Science 236(4799): 280-285.

Tarr, J. A. 1996. The search for the ultimate sink: urban pollution in historical perspective. Ohio: University of Akron Press.

Tsing, A. L. 2005. Friction: an ethnography of global connection. Princeton, NJ: Princeton University Press.

U.S. Environmental Protection Agency. 2008. Indoor air vapor intrusion mitigation approaches. Office of Research and Development, National Risk Management Research Laboratory. EPA/600/R-08-115. October.

- 1994. Model standards and techniques for control of radon in new residential buildings. US Environmental Protection Agency, Air and Radiation (6604-J). EPA 402-R-94-009. March. 1993. Air/Superfund national technical guidance study series: options for developing and evaluating mitigation strategies for indoor air impacts at CERCLA Sites. EPA-451/R-93-012. September.

Walker, P. 2007. Political ecology: where is the politics? Progress in Human Geography 31(3):363369.

Wolf, E. 1999. Envisioning power: ideologies of dominance and crisis. Berkeley: University of California Press. 


\begin{abstract}
This article draws on ethnographic data to explore lived experiences and narratives of mitigation unfolding in a toxic waste site in Endicott, New York, the birthplace of International Business Machines Corporation (IBM) and the location of a contentious U.S. EPA Superfund Site. It introduces the political ecology of mitigation concept and showcases how this critical approach to toxics repair can inform contemporary environmental social science discussions of environmental contamination and risk society. Envisioning the political ecology of mitigation, it is argued, calls for an ethnographic approach cognizant of politics of knowledge and expertise that invoke competing visions of mitigation in general and the efficacy of mitigation technologies and science in particular. Mitigation decisions are political and not simply scientific decisions. The political ecology of mitigation explored here pays close attention to the practices and processes through which toxics mitigation is wielded and negotiated. It shows how such practices and processes may inform contemporary perspectives on toxic neoliberal environments and ecologies.
\end{abstract}

Key words: political ecology, toxics mitigation, IBM, neoliberalism, ethnography

\title{
Résumé
}

Cet article s'appuie sur des données ethnographiques d'explorer les expériences vécues et des récits, des mesures d'atténuation dans un site de déchets toxique à Endicott, New York, la ville natale d'International Business Machines Corporation (IBM) et l'emplacement d'un "EPA Superfund Site" contentieux. Il introduit l'écologie politique du concept d'atténuation et montre comment cette approche de la réparation des substances toxiques peut informer des discussions contemporaines de la "société de contamination" et les risques environnementale. L'écologie politique des mesures d'atténuation, dit-on, demande une approche ethnographique consciente de la politique de connaissances et d'expertise qui invoquent les visions des mesures d'atténuation en général et en particulier l'efficacité des technologies d'atténuation et de la science. Les décisions de mitigation sont politiques et pas simplement scientifiques. L'écologie politique d'atténuation exploré ici accorde une attention particulière aux pratiques et aux processus par lesquels atténuation des substances toxiques est exercé et négocié. Il montre comment de telles pratiques et les processus peuvent informer les perspectives contemporaines sur des "environnements et des écologies néolibérales toxiques."

Mots-clés: écologie politique, atténuation des substances toxiques, IBM, le néolibéralisme, ethnographie

\section{Resumen}

En este artículo se basa en datos etnográficos para explorar experiencias vividas y las narrativas de mitigación en un sitio de desecho tóxico en Endicott, Nueva York, el lugar de nacimiento de International Business Machines Corporation (IBM) y la ubicación de un sitio de Superfund polémicas de Estados Unidos EPA. Introduce la ecología política del concepto de mitigación y vitrinas cómo este enfoque crítico para reparación de tóxicos puede posible informar a discusiones de ciencia social ambiental contemporánea de contaminación y riesgo ambiental de la sociedad. Previendo la ecología política de mitigación, se argumenta, llamadas para un enfoque etnográfico consciente de la política de conocimiento y experiencia que invocar compiten visiones de mitigación en general y la eficacia de las tecnologías de mitigación y ciencia en particular. Las decisiones de mitigación son las decisiones políticas y no simplemente científicas. La ecología política de mitigación explorado aquí presta mucha atención a las prácticas y procesos a través de qué productos tóxicos mitigación es procesos y prácticas ejercieron y negociadas y cómo tales podrán informar a perspectivas contemporáneas sobre entornos neoliberales tóxicos y ecologías.

Palabras clave: Ecología política, mitigación de sustancias tóxicas, IBM, neoliberalismo, etnografía 